\title{
Increasing prosperity for small farms through sustainable livestock production, processing, and marketing
}

\author{
Darin A. Saul, ${ }^{\text {* }}$ Soren M. Newman, ${ }^{\mathrm{b}}$ Tracie Lee, ${ }^{\mathrm{c}}$ Steven Peterson, ${ }^{\mathrm{d}}$ \\ Stephen Devadoss, ${ }^{\mathrm{e}}$ Dev S. Shrestha, ${ }^{\mathrm{f}}$ and Nick Sanyal ${ }^{\mathrm{g}}$ \\ University of Idaho
}

Submitted February 10, 2014 / Revised May 9 and August 21, 2014 / Accepted August 24, 2014 /

Published online November 9, 2014

Citation: Saul, D. A., Newman, S. M., Lee, T., Peterson, S., Devadoss, S, Shrestha, D. S, \& Sanyal, N. (2014). Increasing prosperity for small farms through sustainable livestock production, processing, and marketing. Journal of Agriculture, Food Systems, and Community Development, 5(1), 21-37.

http://dx.doi.org/10.5304/jafscd.2014.051.004

Copyright (C) 2014 by New Leaf Associates, Inc.

\section{Abstract \\ This article presents results from a multidisci- plinary project that examined whether increased production and processing of livestock for local and regional markets was a feasible economic development strategy in rural areas of northern Idaho and eastern Washington. Currently no substantial, accessible feedlot or U.S. Department}

a Interim Director, Office of Community Partnerships, University of Idaho; dsaul@uidaho.edu

${ }^{b}$ Research Associate, Office of Community Partnerships, University of Idaho; newman@uidaho.edu

${ }^{\mathrm{c}}$ Instructor of Operations Management, Department of Business, University of Idaho; tlee@,uidaho.edu

d Instructor of Economics, Department of Business, University of Idaho; stevenp@uidaho.edu

e Professor, Agricultural Economics and Rural Sociology, University of Idaho; sdevadoss@uidaho.edu of Agriculture (USDA)-inspected processing infrastructure exists in the study area, leading most small producers to sell their livestock at auction with few options for branding their products to participate in higher value markets. The closest substantial processing facilities are a four to six hour drive from the area - farther than most producers are willing to transport their livestock. To assess and overcome these barriers to local and regional markets, we explored the viability of

\footnotetext{
${ }^{\mathrm{f}}$ Associate Professor, Department of Biological and Agricultural Engineering, University of Idaho; devs@uidaho.edu

g Associate Professor, Department of Conservation, Social Sciences and Bioregional Planning and Community Design, University of Idaho; nsanyal@,uidaho.edu

* Corresponding author: Darin A. Saul, Office of Community Partnerships, University of Idaho; P.O. Box 442007; Moscow, Idaho 83844 USA; +1-208-885-0124; dsaul@,uidaho.edu
} 
different USDA-inspected processing options to better understand economic feasibility, environmental impacts, and the small-scale livestock production value chain (i.e., consumer demand, producer capacity and willingness to participate, and processing capacity). In this paper, we present results from stakeholder surveys, interviews, forums, and an economic impact analysis. Results indicate that several livestock processing development scenarios are socially, economically, and environmentally viable in the region. Project findings are relevant to many areas of the United States, especially areas of the West, that have low population densities, large transportation distances, and few processing options for small-scale livestock producers.

\section{Keywords}

economic impacts, food systems, local, livestock producer attitudes, regional, USDA-inspected meat processing

\section{Introduction and Literature Review}

While the business model for large-scale agriculture involves specialization, many small farms survive through diversification. Raising livestock can be an important mainstay of or supplement to small diversified farms. Unfortunately, the conventional livestock system includes pricing determined largely by the efficiencies and business models of the largest livestock operations, reducing the viability of small-scale livestock producers. At the same time, many consumers and small producers have become dissatisfied with the industrial food system, resulting in a national resurgence of interest in local foods (Hinrichs \& Welsh, 2003). Sales of locally produced fruits, vegetables, and beef products are on the rise (Springer, Biermacher, Childs, Alkire, \& Grooms, 2009). The revival of farmers markets, community gardens, and food co-ops, the recent media coverage of food safety issues, the use of local foods in restaurants, and the pressure to include sourcing information in grocery stores all represent the increasing market value and consumer interest in local foods.

The increased interest in and demand for locally produced foods is well documented. The Agricultural Sustainability Institute at the
University of California, Davis published a bibliography (2013) that includes over 2,000 articles published in the past 13 years on local and regional food systems. Many consumers prefer meat products sourced locally or produced by someone they know (Winter, 2003) and are willing to pay considerably more for these products (Carpio \& Isengildina-Massa, 2009; Darby, Batte, Ernst, \& Roe, 2008). Restaurants have also increased their purchases of locally grown products in response to consumer interest (National Restaurant Association, 2009).

A growing body of research highlights the potential benefits of small-scale food systems, including rural community revitalization, ecological sustainability, and improved social equity (Brehm \& Eisenhauer, 2008; Feenstra, 1997; Hultine, Cooperband, Curry, \& Gasteyer, 2007). Worosz, Knight, Harris, and Conner (2008) found that local food system participation increases the quality of life for farmers, their employees, and livestock. Some research found that selling to local markets provides economic support for rural areas. Foltz, Jackson-Smith, and Chen (2002) found that smaller, independent farms that market their products directly to local communities support local businesses and stimulate economic activity.

Growing interest in local foods presents an opportunity for small-scale livestock producers to enter higher-profit market niches, potentially increasing the viability and profitability of their operations. Many small-scale livestock producers already participate in local food systems. In the United States, the number of farms that directly market livestock or livestock products to consumers is far greater than those that directly sell fruits and vegetables. In 2007 , more than 79,000 producers reported selling livestock or livestock products directly to consumers, generating over US $\$ 377$ million of revenue (USDA, 2009c). Raising livestock can be an important source of income for small farms, yet many producers face barriers that limit their ability to benefit from consumer demand for locally produced livestock products.

A central barrier for small-scale livestock producers is the result of structural changes in the livestock industry. Technological developments, the drive to increase efficiencies and control costs, 
Figure 1. Map of the Study Region

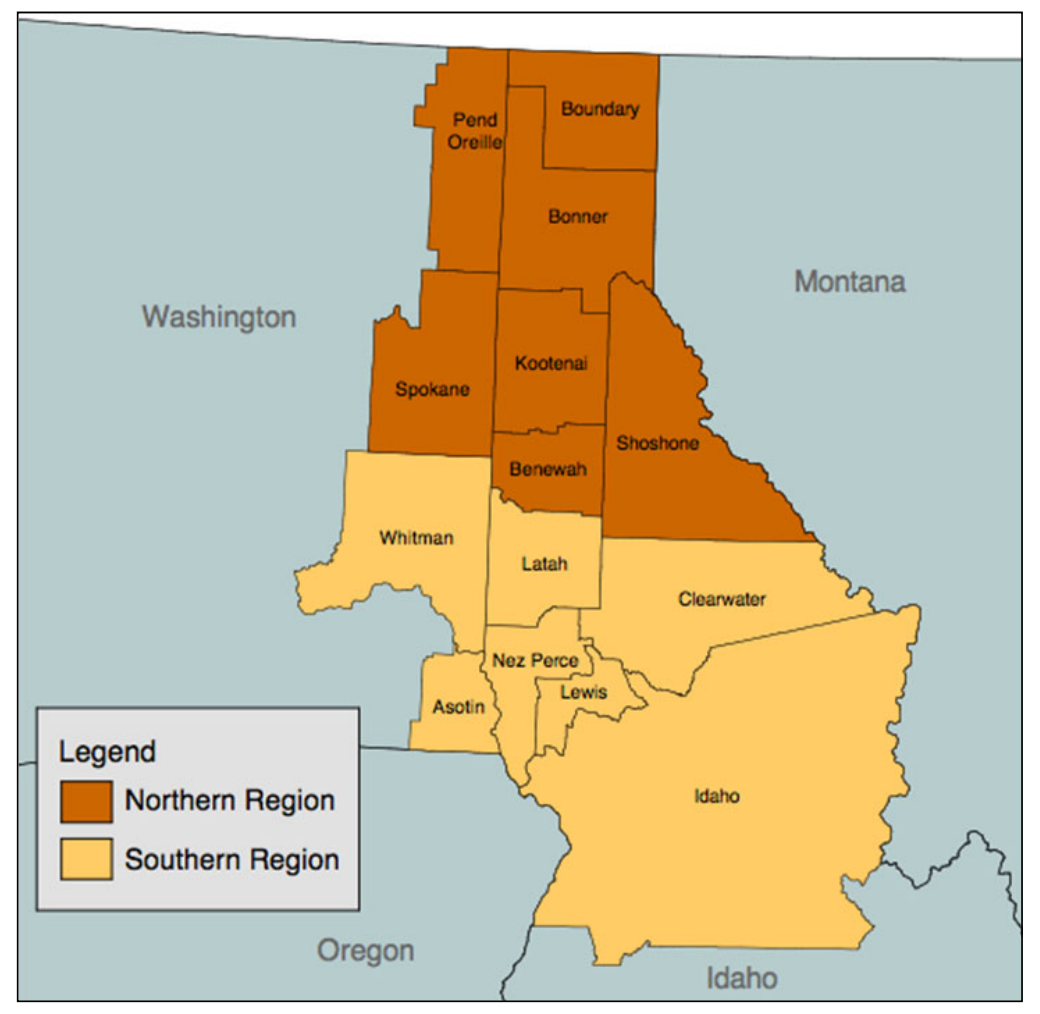

Furthermore, large USDA-inspected plants often charge higher fees for producers with only a few head of cattle, require reservations months in advance, or are not able or interested in working with small producers (Worosz et al., 2008). One strategy for small producers to overcome these barriers is the formation of producer-owned cooperatives (Holcomb, Flynn, \& Kenkel, 2012; McCann \& Montabon, 2012).

\section{Background}

In this article, we present research on the feasibility of developing smallscale, USDA-inspected livestock processing options to increase producer access to higher-profit local and regional markets as an economic development strategy in Idaho's 10 northernmost counties and four adjacent counties in eastern Washington.

The study region was divided into and increasing consumer demand for beef worldwide have played significant roles in the consolidation and vertical integration of feedlots and meat processors (Boehljie, Hofing, \& Schroeder, 1999; Johnson et al., 2012; Lowe \& Gereffi, 2009). Consolidation in the livestock industry into very largevolume plants has resulted in "disintegration of small, localized processing facilities" (Ross, 2006, p. 119). As a result, producers often find themselves competing with hunters at custom-exempt meat processing plants or having to drive several hours to the nearest USDA-inspected facility. ${ }^{1}$

\footnotetext{
${ }^{1}$ Meat processors are businesses that slaughter an animal, cut up the carcass, and package the cuts for a customer. Animals may be harvested from a mobile slaughter unit (MSU) or on a kill floor in the plant. Meat-processing plants in Idaho and Washington are either federally inspected (also called USDAinspected) or custom-exempt. Federally inspected plants have an inspector present during slaughter and the meat can be sold directly to consumers or to wholesalers and distributors. A custom-exempt plant is inspected annually (at a minimum) by the USDA, but an inspector is not present during slaughter; the meat from an animal slaughtered at this plant can be
} northern and southern regions based on where producers were most likely to sell livestock at auction (see Figure 1). In the northern region, producers typically attend the livestock auction in Davenport, Washington. In the southern region, producers attend auctions in Lewiston, Idaho, or in Cottonwood, Idaho.

No substantial, accessible local feedlot or USDA-inspected processing infrastructure exists in the study area, limiting options for producers of any size to retain ownership of their livestock through the finishing and processing stages of production. Small producers in the area typically sell their livestock at auction, with few options for branding their products to participate in highervalue markets. The closest substantial processing facilities are located in the Columbia Basin, a four to six hour drive for most producers in the study area and farther than most are willing to transport their livestock. Furthermore, these facilities are not

consumed only by the producer or sold by the producer while the animal is still alive. 
Figure 2. Potential Regional Livestock Finishing, Processing, and Marketing Options The producer maintains ownership through the grey-shaded steps.

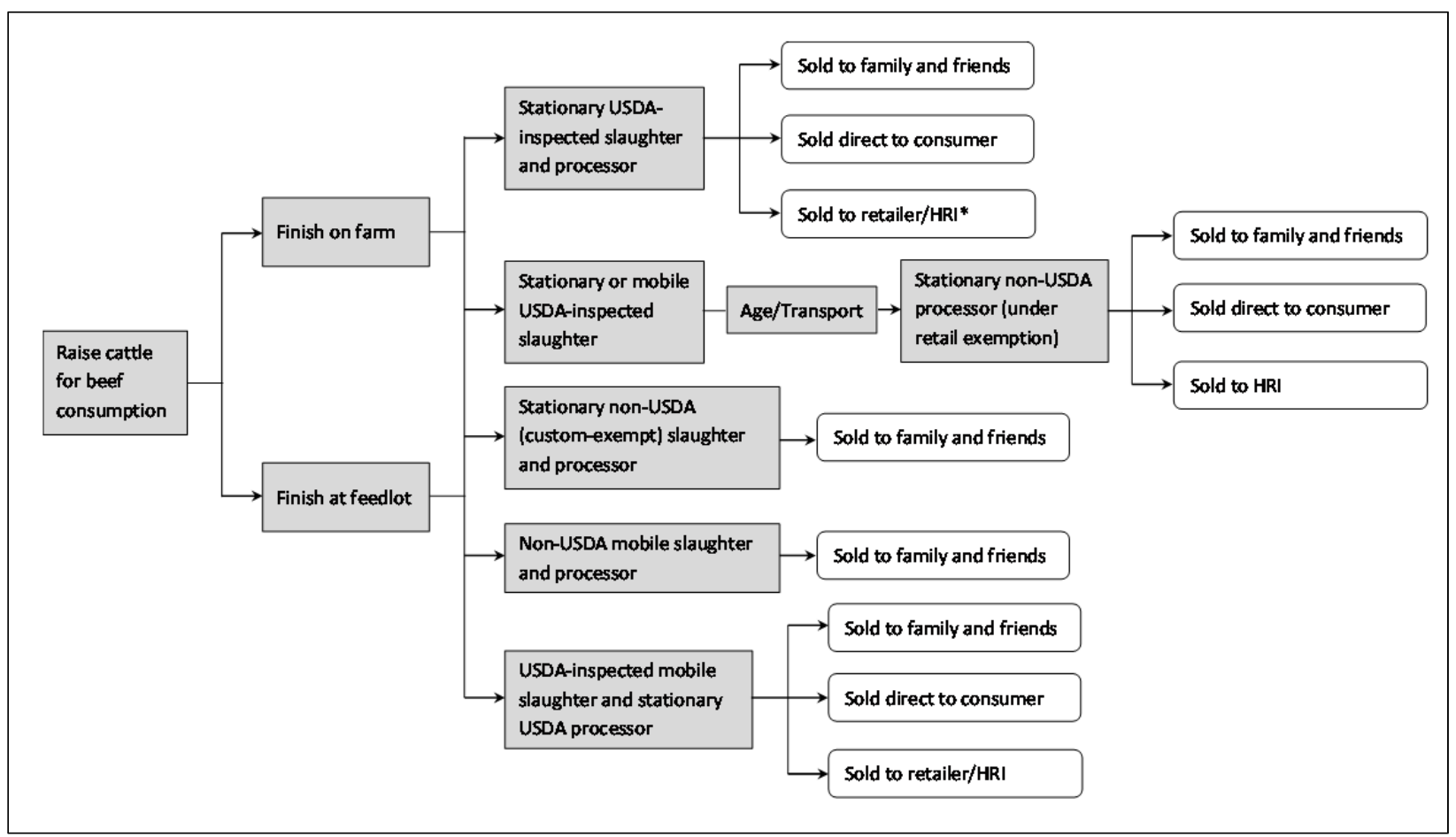

* HRI refers to hotels, restaurants, and institutions.

geared toward, and often are not interested in, working with small numbers of livestock.

Interviews, surveys, and community forums with producers in the 14-county area indicate that the two existing USDA-inspected meat-processing facilities in this study area cannot meet producer demand. These plants are at the University of Idaho in Moscow, Idaho (Latah County), and in Sandpoint, Idaho (Bonner County). Both plants are considered small or very small, in terms of the number of employees and number of livestock processed annually (Johnson et al., 2012). Vandal Meats at the University of Idaho is primarily an educational program and processes a small number of locally raised livestock; the other operation is able to partially meet demand for USDA-inspected processing in the northern third of the study area. Preliminary findings identified inadequate USDAinspected processing capacity within a reasonable driving distance as the primary factor limiting the ability of small-scale livestock producers to produce and market value-added meat products.
Our project examined the feasibility of developing additional USDA-inspected meat processing capacity in the context of consumer demand, environmental tradeoffs, local and regional livestock supply chains, and the economic impacts associated with livestock finishing and processing options (illustrated in Figure 2). We applied an interdisciplinary, mixed-methods approach that collected primary data through surveys, interviews, and stakeholder forums, and used other available forms of data.

To start, we estimated existing and potential markets for locally and regionally produced beef products (Ridley, Devadoss, \& Shook, 2014; Ridley, Shook, \& Devadoss, 2014). Ridley, Devadoss, and Shook (2014) surveyed consumers in northern Idaho and eastern Washington and conducted a conjoint analysis to examine how locality of production, production method, and price of beef and beef products influenced purchasing preferences. ${ }^{2}$

${ }^{2}$ Conjoint analysis uses a practical subset of possible product 
Distance of origin had the strongest effect on consumer preference. On average, the distance threshold to be considered locally grown was approximately 85 miles $(137 \mathrm{~km})$, far below the USDA definition of 400 miles $(644 \mathrm{~km})$. Distance of origin accounted for nearly 60 percent of the total importance of all attributes. Ridley, Devadoss, and Shook (2014) also found that consumers who preferred certified organic and all-natural beef were generally willing to pay a higher price (10 percent more than conventional beef), since they consider these qualities important relative to beef raised with hormones, antibiotics, or vaccinations. Overall the results indicated that consumer interest exists to support development of a locally oriented quality beef economy.

A second project component conducted lifecycle analyses (LCAs) of a small-scale, locally oriented livestock system and of a regional-scale production and processing system to determine environmental benefits and tradeoffs. A first study compared emissions from five small beef operations in the Palouse region of eastern Washington and northern Idaho to emissions from conventional livestock production systems (Roop, Shrestha, \& Saul, 2013). A second study compared emissions from a regional-scale livestock production and processing system to determine the greenhouse gas (GHG) emissions associated with beef production on a regional scale (Roop, Shrestha, Saul, \& Newman, in press). The regional system had slightly lower emissions than the smallscale system, but both systems studied had lower impacts than conventional, national-scale livestock production and processing systems.

In this paper, we present findings for the final two components of the research project: livestock producers' and processors' capacity and willingness to participate, and economic impact analysis. We then discuss each of the component findings in the context of the study as a whole and offer

attribute combinations to identify the relative importance of each attribute in purchasing decisions and is often used to assess the market for locally produced foods (Batte, $\mathrm{Hu}$, Woods, \& Ernst, 2010; Brocklebank, Hobbs, \& Kerr, 2008; Darby et al, 2008; Orme, 2006). conclusions relevant to livestock producers and other professionals.

\section{Methods and Results}

\section{Livestock Producers' and Processors' Capacity and Willingness to Participate}

To better understand livestock producer and processor perspectives on developing livestock processing capacity we focused on several core questions: What are the constraints livestock producers and processors experience in the study region? What processing options are livestock producers interested in pursuing and why? Are a sufficient number of producers willing to participate and, if so, will enough livestock be available to make specific finishing and processing options viable? Finally, to what extent will small-scale processors already in operation in the area support new processing capacity? To address these questions we used 2007 Agricultural Census data and collected primary data through stakeholder forums, interviews, and surveys.

\section{Methods}

Seven stakeholder forums were conducted in the study area from August 2011 to June 2012 in which 142 livestock producers and small-scale processors participated (see Table 1). Forums were primarily used to gather data, disseminate research findings, and involve stakeholders in interpreting results. The researchers facilitated discussions among participants regarding challenges and interests in developing additional processing capacity, as well as the number of livestock producers who would commit to specific finishing and processing options. Detailed notes were kept at each forum and later coded to identify emergent themes in the perspectives of ranchers, processors, and other stakeholders. (The analysis process is described in more depth below.)

A culminating regional forum brought together livestock producers and processors to explore findings and to determine if enough producers were motivated to take further steps to develop livestock processing options in the study area. At the regional forum, evidence of willingness to participate was shown by the formation of an eight-member steer- 
ing committee of livestock producers, which then recruited 26 additional producers for a livestock processing cooperative working group.

To gain a deeper understanding of the lived experiences of producing and processing livestock in the study area, we conducted 19 interviews from May 2011 to July 2012: seven with small-scale livestock producers, 10 with meat-processing facility owners and managers, one with the manager of the Cottonwood (Idaho) Livestock Auction, and one with the manager of a rendering plant in Spokane, Washington. Interviews ranged from one to several hours. Topics covered included motivation, willingness, and interest in participating in different processing options, as well as current experiences, concerns, and constraints. Producers volunteered to participate after researchers announced the opportunity at stakeholder forums.

Starting with an interview with the manager of the University of Idaho USDA-inspected processing facility, we used chain-referral sampling to identify and recruit custom-exempt meat processors representing a variety of business models (e.g., mobile slaughter and in-house cut and wrap, or onsite slaughter and cut and wrap). We also interviewed the owners of the USDA-inspected meat processing plant in the northern part of the study area. The manager of the Spokane rendering plant was included because the plant is the single source for rendering in the study area and was identified by all meat-processing plant managers as a critical component of processing. All interviews were conducted on-site and included a tour of the operation. Interviews with the meat processors and rendering plant managers were audio recorded and transcribed. Participants were asked to review and approve the transcript.

Qualitative data collection and analysis for stakeholder forums and interviews followed a systematic approach. Once the first set of interviews was transcribed and stakeholder forum notes were available, we conducted preliminary coding to label and sort data into theoretical categories. Initial codes and categories were discussed among the research team members to identify and refine
Table 1. Stakeholder Forum Dates, Locations, and Attendance

\begin{tabular}{llc}
\hline Date & Location & Attendees \\
\hline May 2011 & Sandpoint, Idaho & 20 \\
August 2011 & Moscow, Idaho & 23 \\
November 2011 & Lewiston, Idaho & 10 \\
March 2012 & Lewiston, Idaho & 8 \\
April 2012 & Palouse, Washington & 26 \\
May 2012 & Cottonwood, Idaho & 20 \\
June 2012 & Post Falls, Idaho & 35 \\
\hline
\end{tabular}

themes and anomalies, and to ensure intercoder reliability. Through subsequent interviews, preliminary codes were validated or refined, and additional codes emerged. Participants were involved in further refining and interpreting results during stakeholder forums. Finally, codes and categories were organized into key themes and representative quotations were selected.

In addition to forums and interviews, we conducted three surveys: Livestock Producer, Livestock Supply, and Preferred Locations for Livestock Processing surveys. Due to challenges in obtaining a meaningful response rate from this relatively small target population and a primary research objective that did not necessitate a probability sample, we used nonprobability-sampling techniques (Mammen \& Sano, 2012). The Livestock Producer Survey included questions related to livestock processing needs as well as willingness and interest in participating in marketing, feedlot, and processing cooperatives. It was conducted at stakeholder forums and online through the project website. With assistance from the USDA National Agricultural Statistics Service (NASS), letters were mailed to all 2,830 livestock producers in the study area, sorted by county, with annual sales greater than US $\$ 1,000$. Letters were mailed in waves to producers based on when a stakeholder forum meeting was scheduled within about an hour's drive of the recipient. The letter included an invitation to attend the meeting and a link to the online version of the Livestock Producer Survey.

Preliminary stakeholder forum and interview data highlighted a need to collect additional data on 
livestock supply and preferred processing locations. Therefore, the Livestock Supply and Preferred Locations for Livestock Processing surveys were conducted in spring 2012 and fall 2012, respectively, and conducted through the project website, newsletters, and at the final regional forum. These surveys included questions related to the number and type of livestock that would be committed if USDA-inspected processing were available, preferred location for a USDA-inspected processing facility, and willingness to change their livestock birthing cycle. A total of 140 livestock producers responded to surveys.

\section{Producer results}

Data from forums, interviews, and surveys confirmed development of additional slaughter and processing options as a priority for area producers. Most survey respondents said development of additional processing options is either important (28 percent) or very important (60 percent). Producers said the two processing options that would be most helpful for their operations were USDA-inspected on-farm or mobile slaughter (49 percent) and stationary USDA-inspected processing (42 percent). Smaller percentages of producers said non-USDA-inspected stationary processing (2 percent) or non-USDA-inspected on-farm or mobile processing ( 7 percent) would be most useful. Survey and forum data indicate that producers most interested in USDA-inspected processing cooperatives have operations that sell 200 head of beef or fewer each year.

Through forums, interviews, and surveys, producers described factors that motivate their interest in new USDA-inspected processing options. Many participants said that developing USDA-inspected processing capacity in the region would enable them to participate primarily in local markets, thereby circumventing the conventional food system. These producers perceive local food systems as providing a variety of social, economic, environmental, and health benefits. Many of these producers strongly believe a grass-fed diet and mobile slaughter produces a higher-quality product and higher quality of life for livestock animals. As one survey respondent explained,
There is a great demand for smaller-scale farming, better treatment of animals (i.e., not feedlots), grass-fed meat, etc. It would be great to have a mobile USDA facility so animals can be raised on small farms [and not have] to be transported to slaughter facilities. The whole point is to let the animal have a calm and happy existence. Putting animals on trucks breaks that whole cycle.

Many participants who hold this or similar perspectives defined "local" as within a short distance (e.g., the nearest town).

For most livestock producers, the perception that expanded processing capacity will help them overcome current constraints motivates their interest in small-scale USDA-inspected processing. As this producer summarizes, the fundamental challenges confronting livestock producers are a limited number of USDA-inspected processors in the region and the long distances many producers must travel to access them: "We know we have a market, we just need a local USDA processor before we can get into it. We have lots of area for livestock, it was just too damn much hassle to haul them." Sheep and goat producers especially expressed the need for additional processing capacity, since fewer processing options are available to them than for beef producers: "If a USDA facility for lamb and kid processing were located near enough to me, I would like to be actively involved. The lack of processing possibilities for lamb is my single most limiting factor."

Many livestock producers said their current strategy is to save a few animals to sell to family and friends or other consumers in quarters and halves (i.e., direct marketing), and then sell the rest at auction. This type of producer was most likely to state an interest in participating in USDA-inspected processing cooperatives, driven by the potential for higher-profit alternatives to selling animals at auction.

Another common theme relates to overcoming time constraints. Since livestock production is often an activity secondary to off-farm employment or retirement, many producers have limited time to spend on additional livestock-related activities. A commonly expressed problem is that 
while satisfied with their profit on sales of live animals in quarters and halves, they cannot expand because of the time and logistics that direct marketing requires. Therefore, some operations in our study area are at capacity, not because they are limited by how many animals they can raise, but rather by the time it takes to successfully direct market each animal: "Marketing is our weak point - something we don't enjoy or have a lot of time for." In addition to developing USDA-inspected processing capacity, producers experiencing this constraint expressed interest in joining branding and marketing cooperatives so they can expand into retail markets, such as restaurants, and pursue other strategies that do not require as much of their time on the phone to sell each quarter animal.

Some producers want to grow their operations to provide income for additional family members, but do not have the ability to expand animal production. These producers are interested in value-added marketing, moving into markets that require USDA inspection such as restaurants, and other strategies for increasing profits without also increasing production. Producers also mentioned constraints related to current processing in the area. Producers described a mismatch between the timing of their livestock production and processor availability. Some participants noted that a lack of year-round supply could be a constraint to future USDA-inspected processing:

[Processors] are not getting enough cattle in January to March....All calves around here are [born] in spring and for sale after the first of January. What are you going to do when there are no cows available in different seasons? [Producers] want to calve all cows at the same time so they all are ready at the same time. Cheapest way to feed is on grass not hay, so producers calve in spring because mama is on grass while nursing so a lot cheaper than calving in winter and feeding hay.
Livestock Supply Survey respondents were asked if they would be willing to change their birthing cycle for at least a portion of their herd if doing so would make a local USDA-inspected

Figure 3. Percentage of livestock producers who said they would commit to having livestock ready for slaughter by season and livestock type, if altering the birthing cycle for at least a portion of their herd would make a USDA-inspected livestock processing facility feasible.
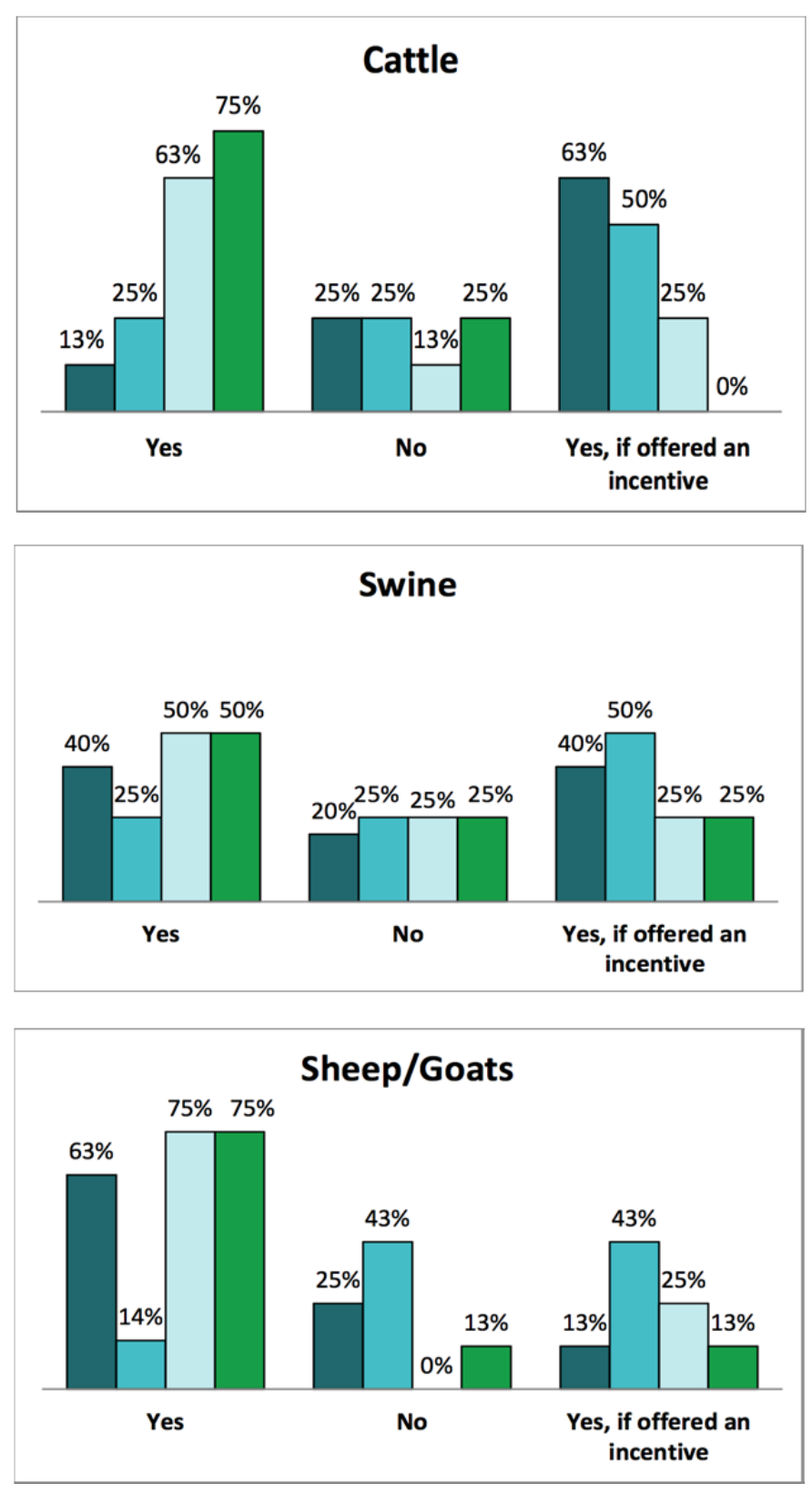

$\square$ November-January $\square$ February-April $\square$ May-July $\square$ August-October 
Figure 4. Distribution of Cattle and Calves Sold (\%), by Number Sold by Operation in 2007

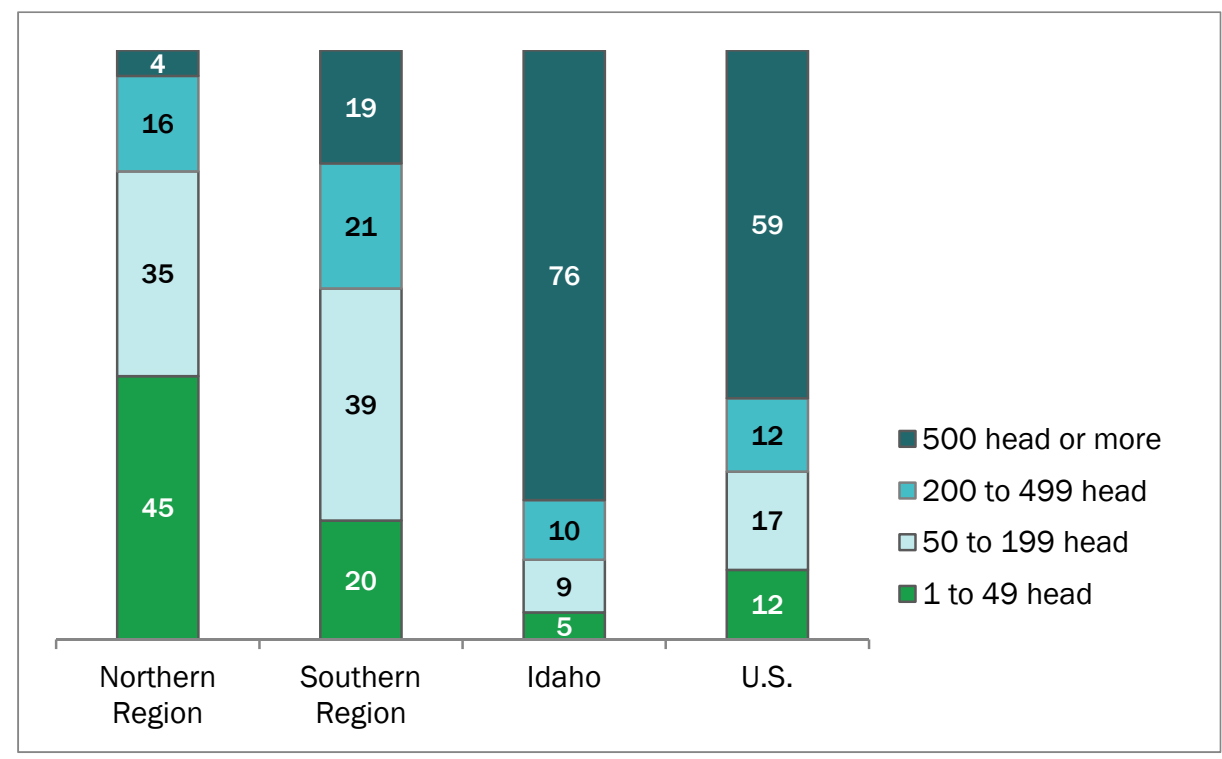

Source: Agricultural Census, 2009a; 2009b.

processing facility feasible (see Figure 3). While 43 percent of producers said they would not commit to having sheep and/or goats ready for slaughter in February-April, only 25 percent or less of producers said they would not alter their birthing cycle, regardless of season or animal type. The majority of producers indicated that they would be willing to alter their livestock birthing cycle to access small-scale, USDA-inspected livestock processing.

Having an adequate supply of livestock to support additional processing capacity is an important consideration. Most livestock in the study area come from small farms where livestock production

Table 2. Number of Livestock Sold in 2007 in the Study Region and Idaho State

\begin{tabular}{lcccc}
\hline Livestock Sold (\#), 2007 & $\begin{array}{c}\text { Northern } \\
\text { Region }\end{array}$ & $\begin{array}{c}\text { Southern } \\
\text { Region }\end{array}$ & $\begin{array}{c}\text { Total Study } \\
\text { Region }\end{array}$ & Idaho State \\
\hline Total Cattle Equivalents* & 27,140 & 57,519 & 84,659 & $1,888,076$ \\
Cattle and Calves & 24,680 & 50,540 & 75,220 & $1,829,456$ \\
Hogs & 6,008 & 17,416 & 23,424 & 65,618 \\
Sheep & 2,743 & 7,040 & 9,783 & 220,481 \\
\hline
\end{tabular}

Source: Agricultural Census, 2009a; 2009b.

* One cattle equivalent is equal to three hogs or six sheep. Sales data for some livestock in some counties were withheld by USDA and are not included in the total. is secondary to off-farm employment or tillage agriculture. According to the Agricultural Census (USDA, 2009a; 2009b), the majority of cattle and calves sold in the study area come from small operations (i.e., those selling fewer than 199 head per year), which distinguishes our study area from the rest of Idaho and Washington, and the nation, where the majority of sales come from operations with 500 head or more (see Figure 4).

In 2007, approximately 85,000 cattleequivalent animals were sold in the study area (see Table 2). Only a small percentage of these would likely be available for a new processing operation. Most livestock are sold at auction, and while many producers are interested in alternatives, many do not have the ability (i.e., available land and feed or access to a local feedlot) to finish animals to slaughter weight. Additional finishing capacity will need to be developed before these producers can significantly participate in local supply chains. Other producers are satisfied with their current local custom-exempt processor or are otherwise not interested in additional options. Also, the study area is large and producers are unlikely and unwilling to transport animals across more than a portion of it, reducing the potential animals available in any particular location. Results of the Livestock Supply Survey provide an estimate of the number of animals producers would be 
interested in committing, either by diverting animals from auction or by raising additional animals, to a new processing operation. Respondents reported that 2,120 cattle, 542 swine, 569 sheep and goats, 13 yaks, and 10 horses would be committed to a new USDA-inspected processing annually if a facility were available. Many more producers expressed interest and potential commitment of animals at the public forums, interviews, and other interactions.

\section{Meat Processor Results}

Interviews with livestock-processing business owners and managers operating in the study area provided insight into current processing capacity and fertile areas for cooperative venture. With the exception of two USDA-inspected processing facilities, processors in the area fall into the custom-exempt category. Most custom-exempt processors supplement their income from livestock processing, which is seasonal, by processing game for hunters, smoking turkey, and making sausage and jerky. As one processor explained it, "Primarily we are a custom operation. I would say probably 80 percent of our business is people bringing us their animals; we slaughter them, process them, cut and wrap them. Most everything leaves frozen."

Custom-exempt processors are subject to annual inspections by the USDA and state food inspection agencies, but do not have a USDA inspector present during slaughter. Without USDA inspection, meat slaughtered and processed by a custom-exempt facility cannot be sold in retail environments such as farmers markets, grocery stores, or at institutions like hotels, schools, or restaurants.

Confirming producer comments, many livestock processors indicated they have periodic unused livestock-processing capacity, especially from March through July of each year: "The busiest time starts about mid-August and will go to the middle of February and then the slow times are the rest." Processors said they would like to process more animals during slow times of the year, but they perceived unwillingness on the part of producers to alter their animals' birthing cycle - a necessary condition to having animals available for processing throughout the winter and spring.
Overall, livestock processors agreed that the development of additional small-scale, USDAinspected processing capacity would benefit the region. Most processors shared the perception that developing additional processing capacity would not hurt existing businesses: "I seriously doubt [a USDA-inspected facility would] take a lot of business from [existing custom-exempt processors like] myself, but maybe in your immediate area." Another processor echoed this perception, hinting at the possibility that new processing would mostly serve a different market than custom-exempt:

I don't feel threatened by it because I think I'm still going to get my loyal customers. They bring me their beef and I cut it up for them, they are the only ones [who] are going to eat it....It probably depends on where the facility gets built, if it gets built. If it's across the street, yeah maybe I'll lose a bit of business.

Both of these quotations indicate the importance of the relationship between livestock producers and their meat processor. The words "loyal" and "relationship" came up often in forum meetings and interviews. Meat processing is a referral-based business for a custom-exempt shop. Processors have a core of loyal customers who refer other producers to the processor; in turn, processors recommend producers to people who call their shop looking for locally raised meat.

Most processors in the study area confirmed that available processing capacity is inadequate to respond to the growing market and producers' demand for USDA-inspected livestock products: "There is plenty of demand and supply. I turn people away every day from September, October, and November for slaughter because I just can't fit it in." They cited three primary factors constraining their ability to meet the growing demand: infrastructure, especially freezer space ("I would need to have more cooler space [and] a little bit more upto-date system. I mean this is a 1967 building."); a limited number of trained employees ("There's always somebody that wants to learn. To find somebody to do it as a career is a little bit tougher."); and retirement plans without a 
succession strategy ("It seems to be a tough industry, not too many people want to get into it....I mean, I would love to train somebody to take it over....I would be ready in 10 years real easy. But so far no one has come down the line for me to do that.").

Processors said they are not planning (or able) to expand to meet the growing demand for USDAinspected livestock processing options. The trends of rising demand and decreasing processing capacity as processors retire will only increase the need to develop additional processing capacity in the study region.

\section{Summary of results for producers and processors}

This component of the project found sufficient producer willingness to participate and a sufficient number of livestock available in the study area to support a variety of processing options. Livestock processors currently in operation do not have the capacity to meet growing demand. Many producers prefer the development of USDA-inspected processing, with either stationary or mobile slaughter options. The majority of producers also expressed interest in developing cooperative local or regional marketing.

\section{Economic Impact Analysis}

Agriculture and the food-processing supply chain make up a small but important part of the overall economy in the study area. In this section, we summarize the expected economic impacts of developing livestock processing in the area and provide economic impacts analysis for the two most promising scenarios: USDA-inspected mobile processing and stationary processing.

\section{Methods}

A social accounting matrix (SAM) model was developed using Minnesota IMPLAN Group's software (Impacts for Planning) and data package (IMPLAN, 2013). The model assessed the contributions to the total economy of the region of different sectors of the economy with a focus on agriculture, food processing, and beef processing. Economic base and profile assessments were conducted using an IMPLAN model for a subset of counties in the southern portion of the study area (Clearwater, Idaho, Latah, Lewis, and Nez Perce counties in Idaho, and Asotin and Whitman counties in Washington) and for the entire study area. The economic base was calculated using the ASAM model developed by Braak, Watson, and Rodriguez (2010). The base assessment identified and reported the actual drivers of the regional economy (Miller \& Blair, 2009).

We then conducted an economic impact assessment of USDA-inspected mobile processing and USDA-inspected stationary processing scenarios. The financial and input data for these analyses came from several sources:

1. A regional survey (including financial information) of local beef and meat producers as part of the supply-chain analysis of the study.

2. A feasibility analysis conducted by Painter (2008).

3. A student-led project analysis: Cost-Benefit Analysis: Creating a USD A Processing Plant in Lewiston, ID or Clarkston, WA (an unpublished report, University of Idaho, Moscow, Idaho).

4. A review of existing studies of small-scale beef and meat producers.

As processing practices and cost information vary more among rural, small-scale processing operations than they do across larger operations where economies of scale foster standardization and uniformity, there was some variance in the financial and input data we used to estimate the economic impacts. Cost differences in available input data were accounted for by calculating averages.

\section{Base and profile assessment results}

The base assessment found that agriculture and food processing constitute about 7.2 percent $(6,303$ jobs) of actual employment and 10.1 percent $(8,811)$ of the employment base (including the multiplier effects) in the study area. Animal processing (all) is only 0.3 percent (268) of actual employment and 0.7 percent (585) of base employment. Cattle ranching constitutes 0.3 percent (252) of the region's employment and 0.2 percent (180) of its 
base. Beef consumption (cooked at home) in the southern subset of the study region is estimated at about US $\$ 16$ million per year, meat consumption is estimated at US $\$ 57.6$ million per year, and overall food consumption is US\$477.4 million per year.

The key conclusion of these analyses is that the economic impacts of the proposed local beef processing alternatives are small, ranging from three to 15 direct employees per operation. Factoring in multiplier effects, eight to 30 jobs could be created. Although these analyses were conducted for the region (representing a cohesive economy), the overall magnitude of the income and job impacts depends on where the new proposed facility is located. The economic assessment suggests that if a facility is located in a rural community (e.g., Palouse, Washington, which has a population of approximately 1,000 people), the economic impact can be significant relative to the local economy. However, if a livestock processing facility is developed and located in one of the larger communities, such as Lewiston, Idaho (population 32,000) or Moscow, Idaho (population 24,000), the impacts will be much smaller relative to the economy. Regardless of the beef-processing alternative chosen (see Figure 2), the economic impacts will be small but not insignificant in the study area.

\section{Scenario Results}

In addition to the base and profile assessments, we conducted detailed analyses of the two most promising USDA-inspected processing scenarios: a mobile processing unit harvesting approximately 450-500 cattle equivalents per year, and a regional stationary facility to be located in a larger community such as Lewiston, harvesting approximately 1,100 cattle equivalents per year.

Composite budgets were created from the data sources cited earlier. The annual expenditures for the mobile processing unit are approximately US $\$ 300,000$ or US $\$ 840,000$, the latter amount including cost and value of the cattle equivalents at US $\$ 1,200$ per head. The annual expenditures for the stationary facility are approximately US $\$ 620,000$ or US $\$ 1,940,000$, including cost and value of the cattle equivalents. These data were entered into the IMPLAN economic model and margins were applied where appropriate (see Table 3)..$^{3}$

The economic impacts of developing livestock processing on employment (full-time-equivalent employees) and on output (sales) are reported in Table 3. The mobile processing unit would directly create three FTEs and US $\$ 807,000$ in direct expenditures (after adjustments). Including the indirect and induced effects, a total of eight jobs would be created and there would be approximately US $\$ 1,529,000$ in output (sales) a year. The output multiplier for the mobile scenario is 1.90 , meaning that for every one dollar of expenditures in final demand, a total of US\$1.90 in output (sales) are created in the regional economy.

For the regional stationary facility, we estimate that seven FTEs would be directly created and the direct expenditures would be US $\$ 1,916,000$ (after adjustments). Total impacts are 19 jobs (including the indirect and induced effects) and US\$3,568

\footnotetext{
${ }^{3}$ Margins adjust the data from the purchaser perspective (purchaser prices) to what the producer receives (producer prices).
} 
thousands in output. The output multiplier for the stationary scenario is 1.86 .

We identify two major opportunities for economic development. The first is to develop an export market for locally grown and processed beef and other related value-added products to be sold out of the study region in cities such as Seattle, Washington, or Portland, Oregon. This could add considerable jobs and income to the region's economic base. A second, more intriguing opportunity represents an import-substitution approach that would develop a complete beef-related local food chain, from birth to home or restaurant. In this case, HRIs (hotels, restaurants, institutions) and retailers or vendors would be systematically brought into closer alignment with producers and processors, cutting down on overall costs to everyone's benefit.

Since modern agriculture has virtually eliminated local food chains, this will create more efficient local markets, building them from scratch. Developing a market for locally produced beef will assist in developing local food chains for all agricultural products. It will create brand loyalties among consumers, enhance and expand existing local markets such as food co-ops and farmers markets, and create economies of scale and scope in supply chain distributions. This approach could create a cluster effect of other complementary, locally produced products, including beef, other meats, and vegetables. The development of livestock processing could contribute to rural communities becoming more self-sufficient while building their local economies. Under certain conditions, an import substitution approach can be as economically beneficial to community development as export-led growth (Cooke \& Watson, 2011).

\section{Discussion and Conclusions}

This study contributes to the growing body of literature exploring how to improve economic viability and environmental sustainability for small and medium-sized farmers. Several reports have been published in recent years evaluating the feasibility of developing slaughter and processing options for livestock producers as growing consumer demand for locally produced meat has created higher-profit and value-added niche markets. For example, small-scale livestock slaughter and processing feasibility studies have been conducted in Nevada (Curtis, Cowee, Lewis, \& Harris, 2008; Curtis et al., 2006), eastern and New England states (Coleman, 2008; Mills, 2007), western Washington (Yorgey, 2008), and California (Schahczenski, 2009). Many commonalities can be identified across cases (e.g., producer willingness to participate in various options, seasonality, market demand, and sufficient livestock supply have been identified as constraining variables), yet most of this work has been conducted in areas with shorter travel distances and higher population densities than the current study.

Despite somewhat unique challenges, all aspects of our research supported the feasibility of developing additional livestock processing capacity. Beginning with market assessment, Ridley, Devadoss, and Shook (2014) found that consumers in northern Idaho and eastern Washington prefer locally raised beef, and that the locality of production was the most important attribute explaining consumer buying preferences. Consumers in the study region also indicated they are willing to pay 10 percent more for organic or all-natural varieties of beef over conventionally produced beef and beef products. This research indicates consumer demand in the region would support the development of USDA-inspected processing capacity that is needed to establish and strengthen a locally oriented beef economy.

For livestock producers in our study area, these growing niche markets provide higher-profit alternatives to selling animals at auction. Yet the agricultural trend of industrialization and concentration over the past decades has contributed to the loss of small, USDA-inspected livestock processing capacity in many rural areas (Ross, 2006; Worosz et al., 2008). Consistent with the broader literature, livestock producers in our study area described inadequate access to USDA-inspected processing options within a reasonable distance of their operation as a major limitation to fuller participation in and benefit from local and regional markets. Along with inadequate processing capacity, three additional themes emerged as significant constraints for area producers: the time required to direct market, 
inadequate income to support multigenerational families, and a mismatch between when existing processors have underutilized capacity and the seasonality of available livestock production.

The custom-exempt processors who participated in this research were not interested in becoming USDA-inspected, but were supportive of working with producers to develop a new business model and new capacity. Forums, interviews, and surveys indicated that USDA-inspected mobile slaughter is the solution producers desired most, followed closely by building a stationary USDAinspected facility. Any solution must address the key issue of smoothing out the seasonality of livestock production to ensure a steady supply for meat processors. Survey results demonstrated significant willingness on the part of producers to alter the birthing cycle for at least a portion of their herd if doing so would increase the feasibility of developing a USDA-inspected livestock processing facility. Substantial numbers of sheep, hogs, and goats are being raised in the area, and additional capacity exists to raise more. Developing a schedule that evens out the seasonality impacts associated with small-scale beef production in the area by processing significant amounts of other livestock could support a more balanced supply to processors while helping address the strongly expressed need for more processing options for sheep, goat, and other livestock.

Through all components of the project we found that consumer demand, livestock supply, and producer willingness to participate are not limitations to developing additional processing capacity in northern Idaho and eastern Washington. That producers have formed an independent group (the Greater Palouse Meat Producers) to take the next steps toward developing a cooperative is a strong indication of producers' motivation to participate. We found strong interest in developing a local-meat food system in all parts of the study area. However, given the general distribution of animals in the study area by county, data from the forums, interviews, and surveys, and feedback from producers and professionals, we focused on the southern portion of the study area as the most promising in terms of having adequate supply and demand for new processing capacity.
We estimate that 8,000 to 16,000 cattle equivalent ${ }^{4}$ livestock are potentially available for a new processing operation in the southern portion of the study area. We present a wide estimate because many producers gave us a range of animals they would contribute based on which processing options ended up being developed. Some who would participate if the option includes mobile slaughter, for example, would still contribute animals, but not as many, to a fixed facility, and some would contribute none. Other available data fluctuated considerably from year to year, including animals sold at auction and animals sold through direct marketing. Given the number and complexity of "what if" options available, we give a range of minimum supply available — the lower boundary accounts for minimum animals available given minimum values for all ranges in the data, and the upper boundary accounts for more optimistic scenarios that include additional processing capacity or options and therefore more capital investment and risk.

In short, enough livestock is raised in the study area to support all processing options we examined. The largest volume scenario we examined requires 8,000 cattle per year to be sustainable. While enough supply to support this strategy exists, it would be a higher risk endeavor, requiring the most change in calving times and finishing options by local producers. Sufficient supply for processing options that require 3,000 animals or fewer exists throughout the study area. The most promising locations based on distribution of supply, need for additional infrastructure, and producer input are in the Pullman-Moscow and Lewiston-Clarkston areas in the southern portion of the study area. The Greater Palouse Meat Producers group is developing a feasibility study that will determine specific animal availability and costs of processing estimates for each option.

While not large, the economic benefits of developing new USDA-inspected processing capacity could be significant in small towns in the area. Impact will be greater in small towns rather than in the small cities identified by producers as

${ }^{4}$ One beef equals three hogs or six sheep. 
the optimal location for a new facility. Multiple locations in the study area are suitable and well located for this type of economic development.

The Life Cycle Analysis by Roop et al. (in press) has showed that both small-scale and regional production and processing have slightly lower than average greenhouse gas emissions than the averages for national-scale systems and systems in other regions of the U.S. Developing additional USDA-inspected processing facilities in the study area will likely produce reduced environmental impacts compared to conventional livestock production and processing, potentially giving producers in the area a marketing edge over producers from other areas of the U.S. in markets valuing environmentally sustainable production.

Overall, this project found that developing additional small-scale, USDA-inspected livestock processing in northern Idaho and eastern Washington is economically, socially, and environmentally feasible. The newly formed producer steering group will build upon this project's research as they develop a detailed business plan, explore financing, and take other steps toward successful expansion of small-scale, USDA-inspected livestock processing as a rural economic development strategy in the area.

\section{Acknowledgements}

The authors would like to gratefully acknowledge funding support from the USDA Agriculture and Food Research Initiative. We wish to thank research assistants Danny Roop, Jennifer Boie, and interns Brita Carr, Nestor Guzman, Casey Hayward, and Sandy Kralik for their contributions to this project. We thank Christy Dearien and Debbie Gray for their involvement with data analysis, editing, and developing figures and tables. We also thank project advisors Steve Shook, Cinda Williams, and Ron Richards.

\section{References}

Agricultural Sustainability Institute. (2013). Community food system resources. Davis, California: University of California, Davis, Sustainable Agriculture Research and Education. http://www.sarep.ucdavis.edu/sfs/CFSresources
Boehlje, M. D., Hofing, S. L., \& Schroeder, R. C. (1999). Value chains in the agricultural industries. West Lafayette, Indiana: Purdue University, Department of Agricultural Economics. Retrieved from http://www.centrec.com/assets/value chains in ag industry.pdf

Braak, W., Watson, P. \& Rodriguez, A. (2010). Automated social account matrix release 3.06. Moscow, Idaho: University of Idaho. http://www.webpages. uidaho.edu/commecondev/asam.html

Brehm, J. M., \& Eisenhauer, B. W. (2008). Motivations for participating in community-supported agriculture and their relationship with community attachment and social capital. Southern Rural Sociology, 23(1), 94-115.

Brocklebank, A. M., Hobbs, J. E., \& Kerr, W. A. (2008). The North American beef industry in transition: New consumer demands and supply chain responses. New York: Nova Science Publishers.

Carpio, C. E., \& Isengildina-Massa, O. (2009). Consumer willingness to pay for locally grown products: The case of South Carolina. Agribusiness, 25(3), 412-426. http://dx.doi.org/10.1002/agr.20210

Coleman, K. (2008). Demand and options for local meat processing: Finding the way from pasture to market in the CT River Valley. South Deerfield, Massachusetts: Community Involved in Sustaining Agriculture. http://www.buylocalfood.org/upload/ resource/Slaughter.FeasibilityStudy2008.pdf

Cooke, S. C., \& Watson, P. (2011). A comparison of regional export enhancement and import substitution economic development strategies. Journal of Regional Analysis and Policy, 41(1), 1-15.

Curtis, K., Cowee, M. W., Acosta, A. R., Hu, W., Lewis, S. R., \& Harris, T. R. (2006). Locally produced livestock processing and marketing feasibility assessment (Technical Report 2006/07-13). Reno, Nevada: University of Nevada, Reno, University Center for Economic Development.

Curtis, K. R., Cowee, M. W., Lewis, S. R., \& Harris, T. R. (2008). Financial potential for livestock slaughter and processing in Nevada (Special Pub. SP-08-01). Reno, Nevada: University of Nevada Cooperative Extension. Retrieved from http://www.researchgate.net/publication/2421861 77 Financial Potential for Livestock Slaughter a nd Processing/file/50463529ccfd7737a0.pdf 
Darby, K., Batte, M. T., Ernst, S., \& Roe, B. (2008). Decomposing local: A conjoint analysis of locally produced foods. American Journal of Agricultural Economics, 90(2), 476-486. http://dx.doi.org/ 10.1111/j.1467-8276.2007.01111.x

Feenstra, G. W. (1997). Local food systems and sustainable communities. American Journal of Alternative Agriculture, 12(01), 28-36. http://dx.doi.org/10.1017/S0889189300007165

Foltz, J. D., Jackson-Smith, D., \& Chen, L. (2002). Do purchasing patterns differ between large and small dairy farms? Econometric evidence from three Wisconsin communities. Agricultural and Resource Economics Review, 31(1), 28-38.

Food, Conservation, and Energy Act. (2008). Washington, D.C.: U.S. Government Printing Office. http://www.gpo.gov/fdsys/pkg/BILLS110hr2419enr/pdf/BILLS-110hr2419enr.pdf

Hinrichs, C. C., \& Welsh, R. (2003). The effects of the industrialization of US livestock agriculture on promoting sustainable production practices. Agriculture and Human Values, 20(2), 125-141. http://dx.doi.org/10.1023/A:1024061425531

Holcomb, R., Flynn, K., \& Kenkel, P. (2012). A feasibility template for small, multi-species meat processing plants. Journal of Extension, 50(5).

Hultine, S. A., Cooperband, L. R., Curry, M. P., \& Gasteyer, S. (2007). Linking small farms to rural communities with local food: A case study of the local food project in Fairbury, Illinois. Community Development, 38(3), 61-76. http://dx.doi.org/10.1080/15575330709489829

IMPLAN. (2013). Software and Data Packages (input/output modeling). Retrieved June 2013 from http://implan.com/V3/Index.php

Johnson, R., Marti, D., \& Gwin, L. (2012). Slaughter and processing options and issues for locally sourced meat (Report No. LDP-M-216-01). Washington, D.C.: USDA, Economic Research Service. http://www.ers.usda.gov/media/820188/ldpm21601.pdf

Krause, J. (2006). Mobile meat processing plant helps small producers. Minneapolis, Minnesota: BEEF. Retrieved from http://beefmagazine.com/ americancowman/small-farm/meat processing

Lowe, M., \& Gereffi, G. (2009). A value chain analysis of the U.S. beef and dairy industries. Durham,
North Carolina: Duke University Social Science Research Institute, Center on Globalization, Governance \& Competitiveness. Retrieved from http://cggc.duke.edu/environment/valuechain analysis/CGGC_BeefDairyReport_2-16-09.pdf

Mammen, S., and Sano, Y. (2012). Gaining access to economically marginalized rural populations: Lessons learned from nonprobability sampling. Rural Sociology, 77(3), 462-482. http://dx.doi.org/ 10.1111/j.1549-0831.2012.00083.x

McCann, N., \& Montabon, F. (2012). Strategies for accessing volume markets in the beef industry: A review of three case studies. Journal of Agriculture, Food Systems, and Community Development, 2(2), 37-49. http://dx.doi.org/10.5304/jafscd.2012.022.014

Miller, R. E., \& Blair, P. D. (2009). Input-output analysis: Foundations and extensions. New York: Cambridge University Press. http://dx.doi.org/10.1017/CBO9780511626982

Mills, S. (2007). Report on the feasibility of a small-scale, small-animal slaughter facility for independent meat producers in North Carolina. Raleigh, North Carolina: North Carolina Department of Agriculture \& Consumer Services. Retrieved from http://www.ncagr.gov/markets/shared-use slaughter report final without appendices.pdf

National Restaurant Association. (2009). Chef survey: What's hot in 2009. Retrieved from http://www.restaurant.org/pdfs/research/2009 chefsurvey.pdf

Orme, B. K. (2006). Getting started with conjoint analysis: Strategies for product design and pricing research. Madison, Wisconsin: Research Publishers.

Painter, K. (2008). Feasibility analysis of a mobile slaughter unit. Moscow, Idaho: University of Idaho. https://www.extension.org/mediawiki/files/6/6a/ Mobile Slaughter Unit Cost Calculator 18May09.pdf

Ridley, W., S. Devadoss, S., \& Shook, S. R. (2014). Estimations of consumer demand for local beef. Journal of International Food \& Agribusiness Marketing, 26(3), 20-36.

Ridley, W., S. Shook, S. R., \& Devadoss, S. (2014). Evaluations of consumers' preference structure for locally-produced beef. Journal of Food Products Marketing, 21(4), 1-18. 
Roop, D. J., Shrestha, D. S., \& Saul, D. A. (2013). Cradle-to-gate life cycle assessment of locally produced beef in the Palouse region of the northwestern U.S. Transactions of the American Society of Agricultural and Biological Engineers, 56(5), 19331941.

Roop, D. J., Shrestha, D. S., Saul, D. A., \& Newman, S. (in press). Cradle-to-gate life cycle assessment of regionally produced beef in the northwestern U.S. Transactions of the American Society of Agricultural and Biological Engineers.

Ross, N. J. (2006). How civic is it? Success stories in locally focused agriculture in Maine. Renewable Agriculture and Food Systems, 21(2), 114-123. http://dx.doi.org/10.1079/RAF2005134

Schahczenski, J. (2009). Final report: Natural livestock feasibility study. Davis, CA: National Center for Appropriate Technology.

Selfa, T., \& Qazi, J. (2005). Place, taste, or face-to-face? Understanding producer-consumer networks in "local" food systems in Washington State. Agriculture and Human Values, 22(4), 451-464. http://dx.doi.org/10.1007/s10460-005-3401-0

Springer, J. D., Biermacher, J. T., Childs, M. D., Alkire, D. O., \& Grooms, B. (2009). Attributes preferred and premiums offered for naturally produced beef cattle. Presented at the Southern Agricultural Economics Association Annual Meeting, Atlanta, Georgia. Retrieved from http://ageconsearch.umn.edu/bitstream/46859/2/ SAEA \%202009\%20JB \%20JS.pdf

U.S. Department of Agriculture [USDA]. (2009a). 2007 Census of agriculture, volume 1 chapter 2: County-level data: Idabo. Washington, D.C.: USDA, Agricultural
Statistics Service. Retrieved October 30, 2013, from http://www.agcensus.usda.gov/Publications/2007 /Full Report/Volume 1, Chapter 2 County Lev el/Idaho/

USDA. (2009b). 2007 Census of agriculture, volume 1 chapter 2: County-level data: Washington. Washington, D.C.: USDA, Agricultural Statistics Service. Retrieved October 30, 2013, from http://www.agcensus.usda.gov/Publications/2007 LFull Report/Volume 1, Chapter 2 County Lev el/Washington/

USDA. (2009c). Summary and state data, volume 1, geographic area series, part 51. Washington, D.C.: USDA, Agricultural Statistics Service. Retrieved from http://www.agcensus.usda.gov/Publications/2007 LFull Report/usv1.pdf

Winter, M. (2003). Embeddedness, the new food economy and defensive localism. Journal of Rural Studies, 19(1), 23-32. http://dx.doi.org/10.1016/S0743-0167(02)00053-0

Worosz, M. R., Knight, A. J., Harris, C. K., \& Conner, D. S. (2008). Barriers to entry into the specialty red meat sector: The role of food safety regulation. Southern Rural Sociology, 23(1), 170-207.

Yorgey, G. (2008). Local meat for local meals: An assessment of demand for a mobile slaughtering unit in Pierce, King, Kitsap and Thurston Counties, for the Puget Sound Meat Producers Cooperative. (master's thesis), University of Washington, Seattle, Daniel J. Evans School of Public Affairs. https://www.extension.org/mediawiki/files/d/d7/ LocalMeatforLocalMeals Puget Sound Meat Coop.pdf 